\title{
Variation in Methane Concentration Produced from Anaerobically Digested Vegetables
}

\author{
H. Mousa ${ }^{* a, b}$ and M. Silwadic \\ a Sultan Qaboos University, Department of Petroleum and Chemical Engineering, P.O. Box 33, Al Khoud P.C. 123, Muscat, Oman. \\ ${ }^{b}$ Jordan University of Science and Technology, Department of Chemical Engineering, P. O. Box 3030, Irbid 22110, Jordan. \\ c Higher College of Technology, Applied Science Department, P. O. Box 74, Al-Khuwair, P.C. 133, Oman.
}

Received 17 February 2015; Accepted 16 April 2015

\begin{abstract}
Anaerobic fermentation is a highly promising technology for converting biomass waste into methane, which then may directly be used as an energy source. Attempts have been made to optimize various parameters in order to determine the most favorable recipe for maximum biogas production from fermented vegetable waste. The biogas production from many types of vegetable waste such as zucchini, orange peel, tomato, potato, and rice was studied in batch digesters. The effect of adding chicken dung and sludge to vegetable waste on the concentration of methane in the produced biogas was investigated. The experiments were conducted at room temperature $\left(20^{\circ} \mathrm{C}\right)$ and at $35^{\circ} \mathrm{C}$. The results revealed that methane concentration goes through maximum value with time. This maximum value is obtained faster when the rate of digestion is faster. The concentrations of methane in the biogas produced are ranked as follows: potato>rice>tomato>zucchini>orange peels. The concentrations of methane gas increased as chicken dung and sludge were mixed with the vegetables. The maximum value of methane concentration is reached faster in a mixture of chicken dung and sludge. For both chicken dung and sludge, the maximum value is reached at the same time.
\end{abstract}

Keywords: Biogas, Methane, Carbon dioxide, Renewable energy, Fermentation, Chicken dung, Sludge, Anaerobic digestion.

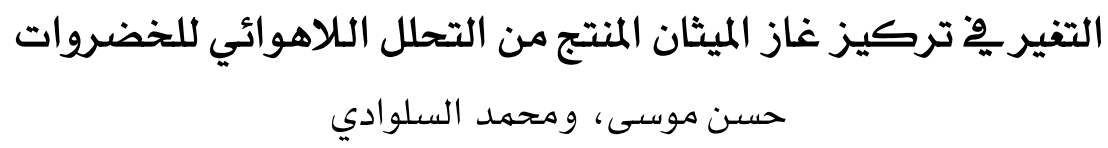

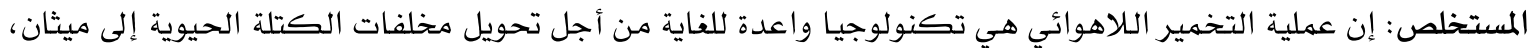

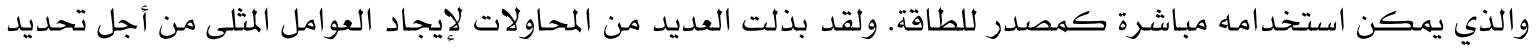

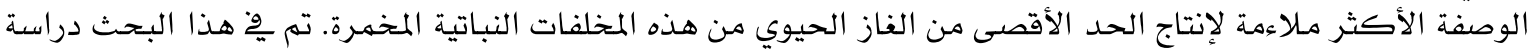

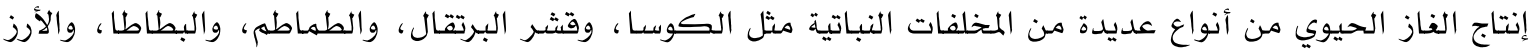

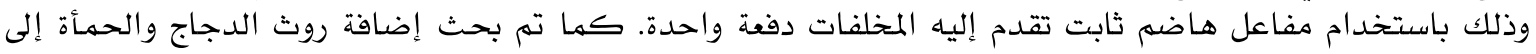

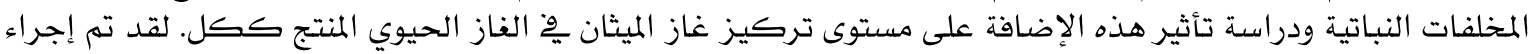

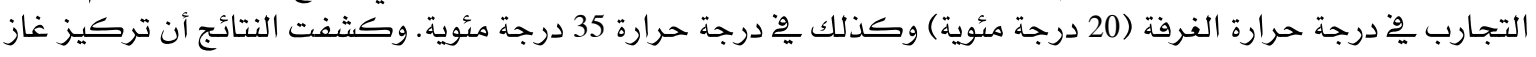

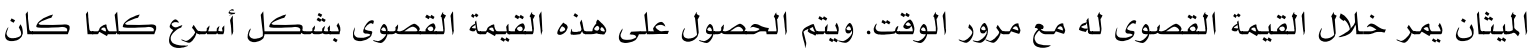

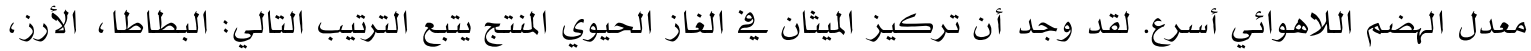

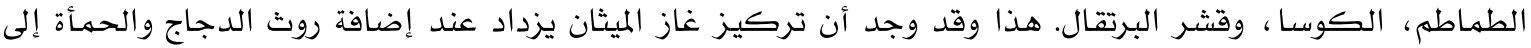

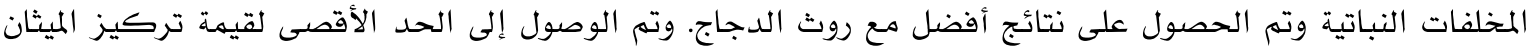

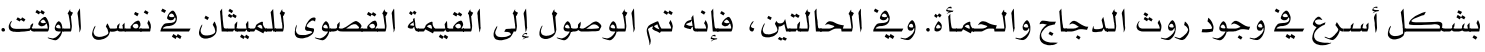
الكلمات المفتاحية : الغاز الحيوي، الميثان، ثاني أكسيد الكريون، الطاقة المتجددة، عملية التخمير، روث الدجاج، الحمأة، التحلل اللاهوائي. 


\section{Introduction}

Due to its high biodegradability, the anaerobic digestion (AD) of organic waste could play a role as an unconventional nonrenewable source of energy. A great deal of research has been conducted to study biogas production from different mixtures of organic waste (Bouallangui 2005; Berlian et al. 2013; Demirbas 2006; Singh et al. 2012; Velmurugan and Ramanujam 2011; Yogita et al. 2012). Various studies have been performed investigating biogas production from fruits and vegetable such as rice (Okeh et al. 2014; Ofoefule et al. 2011), potatoes (Cheng et al. 2011; Bernd 2006; Kryvoruchko et al. 2009; Mayer 1998; Parawira et al. 2004; Parawira et al. 2005), orange peels (Nguyen 2013; Wikandari et al. 2014; Periyasamy and Nagarajan 2012), zucchini (Salter 2007), tomatoes (Saev et al. 2009; Sarada and Joseph 1994), olive pomace (Tekin and Dalgic 2000), banana peels (Nirmala et al. 1996) as well as many other types of organic waste (Velmurugan and Ramanujam 2011). Past research has shown that on average $200-400 \mathrm{ml}$ of biogas can be produced per gram of volatile organic solids (Velmurugan et al. 2011). The productivity of the biogas is affected by the $\mathrm{pH}$ of the reactor, the organic loading rate, the temperature of the waste, the type of organic waste used, and the mixture of the reactor and water contents (Babaee and Shayegan 2010; Bouallagui et al. 2004; Bouallagui et al. 2005; Weiland 2011). The biogas produced by the AD process contains $60 \%$ methane and $40 \% \mathrm{CO}_{2}$ as well as traces of other gases such as hydrogen sulfide, ammonia, nitrogen, and hydrogen. The anaerobic conversion of organic waste to biogas goes through four main steps: hydrolysis, acidogenesis, acetogenesis, and methanogenisis, with the latter responsible for methane gas production. Accordingly, the digestion time, called hydraulic retention time (HRT), is a crucial parameter in maximizing the quantity of the biogas and its methane content. Accordingly, the methane composition of the biogas is expected to increase with time, reaching a maximum value at which it is recommended to withdraw the biogas for energy generation purposes. In this paper, the maximum concentration of methane gas in the biogas produced from potatoes, zucchini, orange peels, rice, and tomatoes will be determined. The effect of mixing such vegetables with sludge and chicken manure as well as the digestion temperature and the time at which the maxima is reached will also be investigated.

\section{Experimental Setup}

The experiments were carried out in $2.25 \mathrm{~L}$ plastic bottles, which were used as bioreactors. To ease gas sampling, the caps of the bottles were pierced, allowing hollow screws to go through. The screws were tightened well to the bottles' cap to prevent any gas leak. Plastic pipes were connected tightly to the outer part of the screws and sealed by clamps. When gas analysis was needed, the clamps were slightly loosened to allow the gas to be released [Fig. 1]. The study was conducted using potatoes, zucchini, tomatoes, and orange peels which were bought from the local market, cut into pieces $\sim 2 \mathrm{~cm}$ in dimension. Then, 500 grams of a given vegetable were placed in a bottle and 500 grams of tap water were added so that the ratio of the solid waste to water was 1:1. Three sets of these bottles were prepared. To each bottle in the second set, $25 \mathrm{ml}$ of chicken dung was added and mixed with the water and vegetable waste. Likewise, $25 \mathrm{ml}$ of sludge was added to each bottle in set three and mixed with its contents. This allowed a study of the effect of chicken manure and sludge on the concentration of methane in the produced biogas. The bottles were prepared in triplicate in order to assure reproducibility of the results. The chicken dung was obtained from a nearby agricultural school and the sludge was obtained from the waste water treatment plant at Jordan University of Science and Technology (JUST). The experiments were performed at room temperature $\left(20^{\circ} \mathrm{C}\right)$ by placing the bottles on the shelves in the lab and at $35^{\circ} \mathrm{C}$ by placing the third set of bottles in an incubator. The produced biogas was analyzed by withdrawing the gas via a $20 \mathrm{ml}$ syringe and then introducing the withdrawn sample to the gas analyzer (EAGLE Type gas analyzer, Union City, California, USA). The volatile solid content (VS) of each batch of vegetable waste, chicken dung, and sludge was determined $a$ priori according to standard methods (APHA, 1995).

\section{Results and Discussion}

\subsection{Water and Volatile Solids Content}

The percentage of water of the selected organics is shown in Table 1. The dried samples were analyzed for their volatile solid (VS) contents and the results are presented as kilograms of $\mathrm{VS} / \mathrm{kg}$ of dry solids [Table 1]. The results indicate that rice contains the lowest water content and the maximum VS whereas wastewater sludge has the highest amount of water and the lowest amount of VS. 


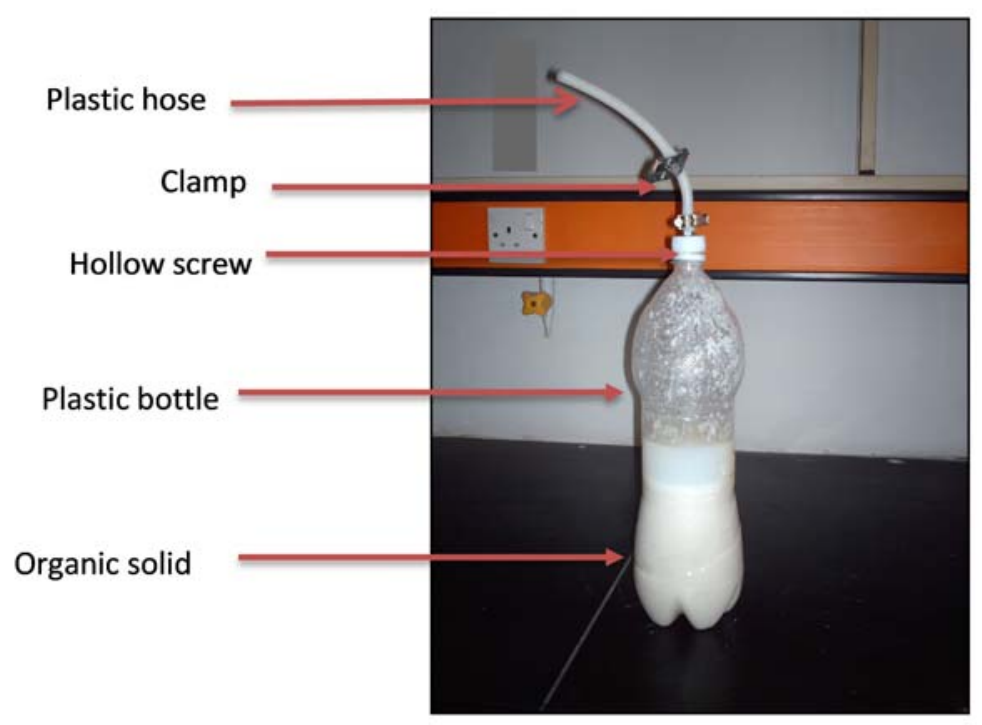

Figure 1. A photograph of the bottle containing solid waste.

Table 1. Water content of tested solid wastes.

\begin{tabular}{lcc}
\hline \multicolumn{1}{c}{ Waste type } & \% water content & VS (VS/kg dry solid) $\times \mathbf{1 0 0} \mathbf{0}$ \\
\hline Rice & $65.82 \pm 3.3$ & $99.14 \pm 0.25$ \\
Potato & $81.46 \pm 2.44$ & $95.15 \pm 0.42$ \\
Tomato & $95.19 \pm 0.36$ & $82.44 \pm 1.59$ \\
Zucchini & $94.55 \pm 0.53$ & $83.62 \pm 0.82$ \\
Orange peel & $77.17 \pm 0.02$ & $96.84 \pm 0.8$ \\
Chicken dung & $20.96 \pm 0.43$ & $86.28 \pm 0.49$ \\
Sludge & $97.05 \pm 0.15$ & $71.28 \pm 0.8$ \\
\hline
\end{tabular}

\section{2 $\mathrm{CH}_{4}$ Concentration in the Produced Biogas}

A comparison between the concentrations of methane gas in the biogas produced by the solid waste tested at $35^{\circ} \mathrm{C}$ is shown in Fig. 2. Potato was found to give biogas with a higher $\mathrm{CH}_{4}$ content compared to rice. Table 2 shows that potato has higher potassium content compared to rice, explaining the higher content of methane in the biogas produced (Machnica et al. 2008). Orange peels, however, have a higher VS content but contain D-limonene oil that upsets the function of the anaerobic bacteria which explains the low methane content of the biogas (Martin et al. 2010). The acidity of tomatoes negatively affects the productivity of the bacteria causing lower methane production. Figure 2 shows that methane concentration is achieved through a maximum time value which is reached at different times according to the solid used. It can be noted that the faster the biodegradation process, the higher the maximum. The time necessary follows an order from high to low: potatoes $>$ rice $>$ tomatoes $>$ zucchini $>$ orange peels. This point needs further investigation and must be related to the amount of biogas produced to draw a solid conclusion. The amount of biogas produced and its methane concentration are important factors to determine the optimum HRT.

The effect of temperature on the amount of bigas produced is presented in Figs. 3a-d for zucchini, potatoes, tomatoes, and orange peels, respectively. The results are in accordance with other researchers' findings where biogas of higher methane concentrations is produced at higher temperatures (Beam 2011; Nallathambi 2004; Chua 


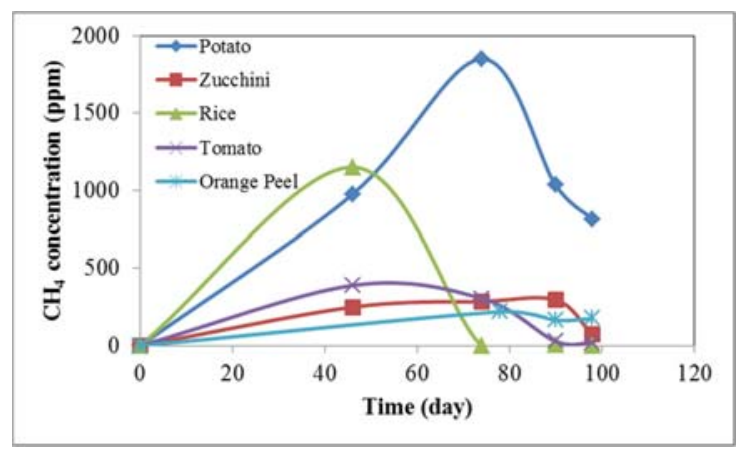

Figure 2. Methane concentration in the biogas produced from the various solid wastes at $35^{\circ} \mathrm{C}$.

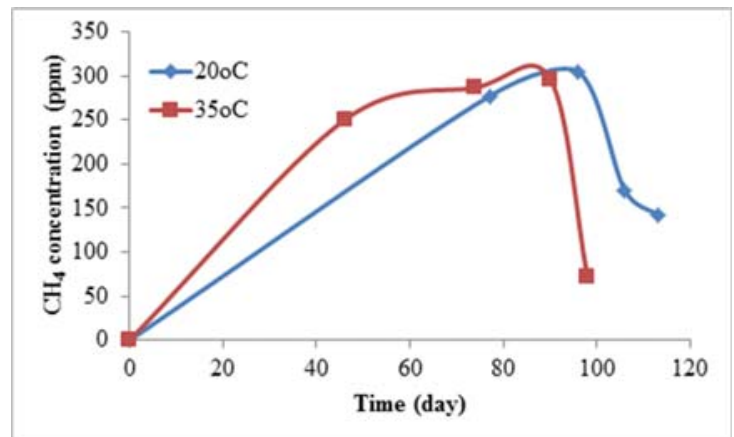

Figure 3a. Methane concentration in biogas produced from zucchini at $20^{\circ} \mathrm{C}$ and $35^{\circ} \mathrm{C}$.

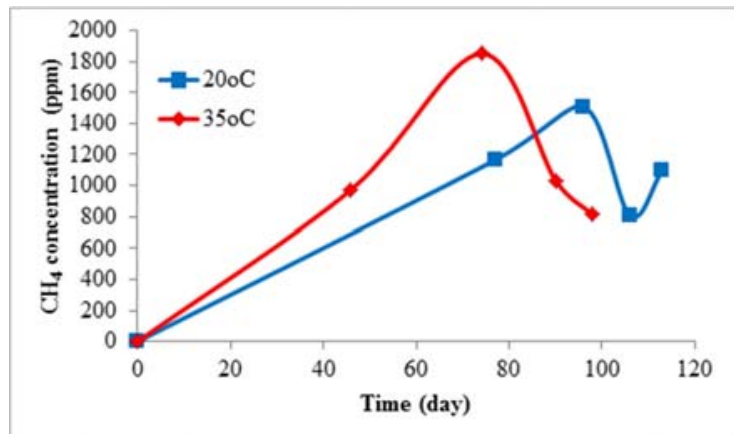

Figure $3 \mathbf{b}$. Methane concentration in the biogas produced from potato at $20^{\circ} \mathrm{C}$ and $35^{\circ} \mathrm{C}$.

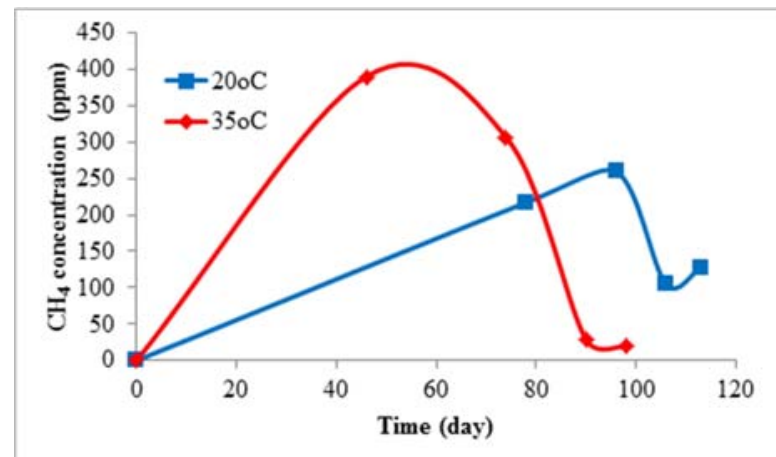

Figure 3c. Methane concentrations in the biogas produced from tomatoes at $20^{\circ} \mathrm{C}$ and $35^{\circ} \mathrm{C}$. 


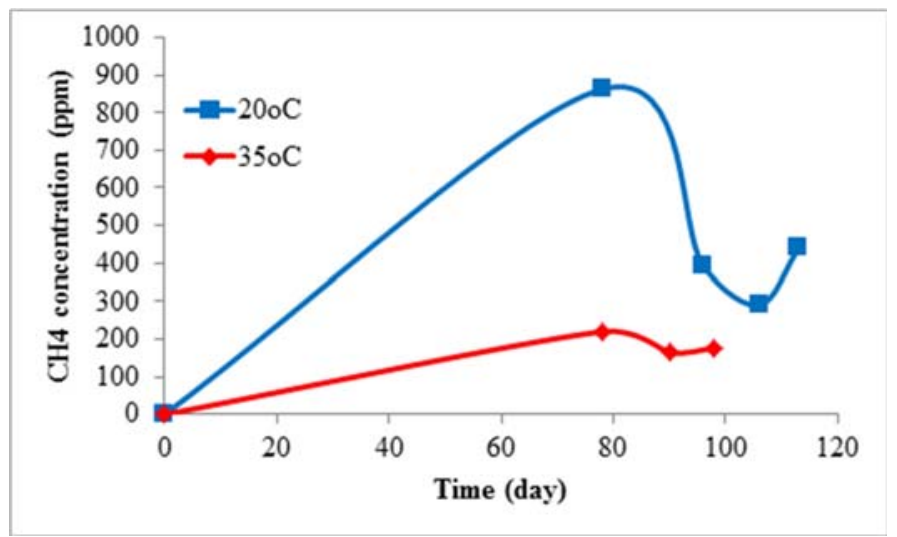

Figure 3d. Methane concentration in the biogas produced from orange peels at $20^{\circ} \mathrm{C}$ and $35^{\circ} \mathrm{C}$.

et al. 2013). Except for orange peels, biogas of a higher methane concentration is produced at $35^{\circ} \mathrm{C}$ compared to $20^{\circ} \mathrm{C}$. The effect is strong for potato and tomato and weak for zucchini. Moreover the maxima are achieved at shorter times when the temperature is higher and the rate of degredation is faster. For orange peels, biogas of a lower methane concentration is produced at $35^{\circ} \mathrm{C}$ as compared to $20^{\circ} \mathrm{C}$ because D-limonene becomes unstable at low temperatures. Since D-limonene negatively affects the bacterial activity, oxidation causes its concentration to drop, enhancing the activity of the bacteria and leading to higher biogas production at $20^{\circ} \mathrm{C}$ compared to $35^{\circ} \mathrm{C}$ (Martin et al. 2010; Paramita et al. 2010).

The effect of adding sludge to the vegetable waste on the concentration of methane in the biogas is depicted in Fig. 4a-d. The presence of sludge increases the concentration of methane gas produced and its maximum is achieved faster. This is obvious since sludge enhances the rate of methane production a result similar to that obtained by (Liu et al. 2009; Satayanarayana et al. 2008; Gelegenis et al. 2007). A comparison between the effect of adding sludge and chicken dung to zucchini is depicted in Fig. 4a. Biogas with a higher methane concentration is produced when chicken dung is added; however, chicken dung and sludge achieve maximum methane levels at the same time. A careful inspection of the figures shows that after the methane gas concentration drops from its maximum value, it reaches a minimum value and again increases. A possible explanation is that methanogenic bacteria transforms the volatile fatty acids (VFA) formed by the acidogenesis bacteria into methane gas. Accordingly, the VFA concentration drops and so does the methane gas level. This drives the activity of acidogenesis bacteria to produce VFA, producing an acidic environment (low $\mathrm{pH}$ ). As a consequence of this drop, the activity of acidogenesis bacteria drops and metthanogenic bacteria utilize VFA to produce methane, causing an increase in its concentration and the cycle repeats. This point is not proven in this work but worth investigation in future research.

\section{Conclusions}

In the current study, anaerobic digestion of vegetable waste was carried out in batch digesters. The concentration of methane in the biogas produced from zucchini, potatoes, tomatoes, rice, and orange peels was measured. The effect of adding chicken dung and sludge to the above named vegetables on the concentration of methane was investigated. The work was carried out at $20^{\circ} \mathrm{C}$ and $35^{\circ} \mathrm{C}$. The concentration of methane excreted from the vegetables studied is as follows: potato $>$ rice $>$ tomato $>$ zucchini $>$ orange peel. The concentration of methane achieves a maximum, and that maximum is achieved faster in tandem with the rate of digestion. Sludge, chicken dung, and temperature improved the concentration of methane in the biogas, and the maximum value is reached earlier. The produced biogas has a higher methane concentration when chicken dung is used; however, a maximum methane concentration is reached at nearly the same time whether chicken dung or sludge is used. 


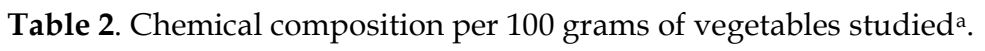

\begin{tabular}{|c|c|c|c|c|c|}
\hline Component & Rice & Potatoes & Zucchini & Orange Peels & Tomatoes \\
\hline Protein (g) & 7.1 & 2.0 & 1.2 & 1.5 & 0.9 \\
\hline Fat (g) & 0.66 & 0.09 & 0.2 & 0.2 & 0.2 \\
\hline Carbohydrates (g) & 80 & 17 & 2.9 & 25 & 4.7 \\
\hline Fiber (g) & 1.3 & 2.2 & 1.1 & 10.6 & 1.2 \\
\hline Sugar (g) & 0.12 & 0.78 & - & - & 2.6 \\
\hline Calcium (mg) & 28 & 12 & 21.4 & 161 & 13 \\
\hline Iron (mg) & 0.8 & 0.78 & 0.35 & 0.8 & 0.5 \\
\hline Magnesium (mg) & 25 & 23 & 17 & 22 & 11 \\
\hline Phosphorus (mg) & 115 & 57 & 51.4 & 21 & 24 \\
\hline Potassium (mg) & 115 & 421 & 262 & 212 & 237 \\
\hline Sodium (mg) & 5 & 6 & 10 & 3 & 3 \\
\hline Zinc (mg) & 1.09 & 0.29 & 0.29 & 0.25 & - \\
\hline Copper (mg) & 0.22 & 0.11 & .051 & - & - \\
\hline Manganese (mg) & 1.09 & 0.15 & 0.175 & - & 0.114 \\
\hline Selenium ( $\mu g)$ & 15.1 & 0.3 & 0.58 & - & - \\
\hline Vitamin C (mg) & 0 & 19.7 & 17 & 136 & 14 \\
\hline Thiamin (mg) & 0.07 & 0.08 & - & 0.12 & 0.037 \\
\hline Riboflavin (mg) & 0.05 & 0.03 & - & 0.09 & - \\
\hline Niacin (mg) & 1.6 & 1.05 & 0.487 & 0.9 & 0.594 \\
\hline Pantothenic acid (mg) & 1.01 & 0.30 & 0.155 & - & - \\
\hline Vitamin B6 (mg) & 0.16 & 0.30 & 0.218 & 0.176 & 0.08 \\
\hline Folate total $(\mu \mathrm{g})$ & 8 & 16 & 48 & - & - \\
\hline Vitamin A (IU) & 0 & 2 & - & 420 & 42 \\
\hline $\begin{array}{l}\text { Vitamin E, alpha-tocopherol } \\
(\mathrm{mg})\end{array}$ & 0.11 & 0.01 & - & 0.25 & 0.54 \\
\hline Vitamin K1 $(\mu \mathrm{g})$ & 0.1 & 1.9 & - & - & 7.9 \\
\hline Beta-carotene $(\mu \mathrm{g})$ & 0 & 1 & - & - & 449 \\
\hline Lutein + zeaxanthin $(\mu \mathrm{g})$ & 0 & 8 & - & - & 123 \\
\hline Saturated fatty acids (g) & 0.18 & 0.03 & 0 & 0.024 & - \\
\hline $\begin{array}{l}\text { Monounsaturated fatty } \\
\text { acids }(\mathrm{g})\end{array}$ & 0.21 & 0.00 & 0 & 0.036 & - \\
\hline Polyunsaturated fatty acids (g) & 0.18 & 0.04 & 0.1 & 0.04 & - \\
\hline
\end{tabular}




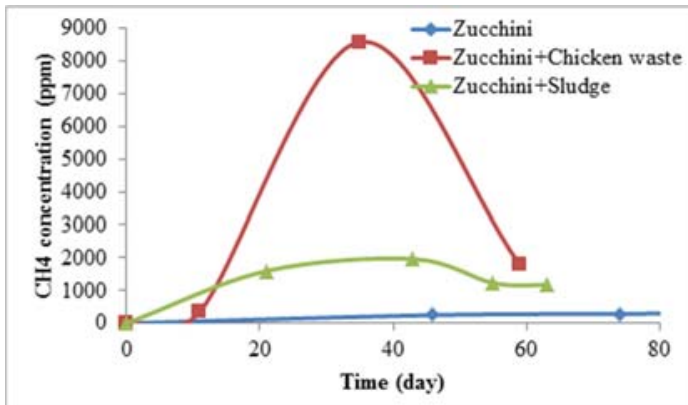

Figure 4-a. Methane gas concentration in the biogas produced from zucchini in the presence of sludge, and chicken dung as an inoculum $35^{\circ} \mathrm{C}$.

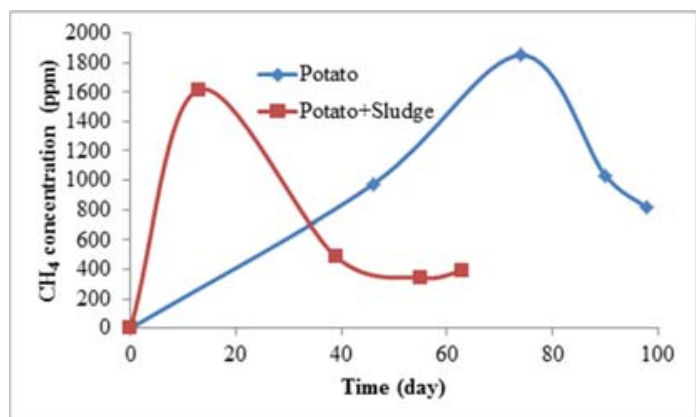

Figure 4-b. Methane gas concentration in the biogas produced from potatoes with and without sludge $\left(\mathrm{T}=35^{\circ} \mathrm{C}\right)$.

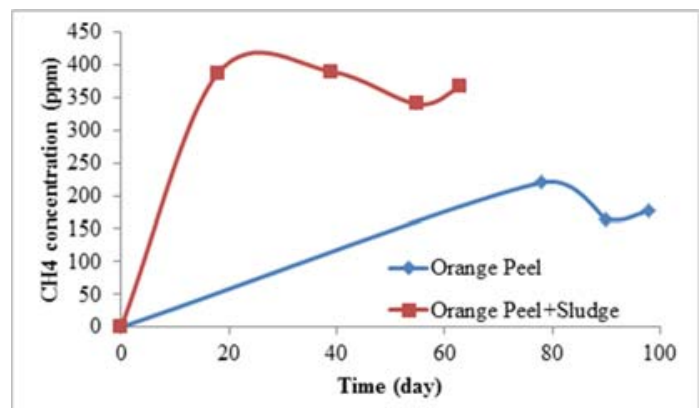

Figure 4-c. Methane gas concentration in the biogas produced from orange peels with and without sludge $\left(\mathrm{T}=35^{\circ} \mathrm{C}\right)$.

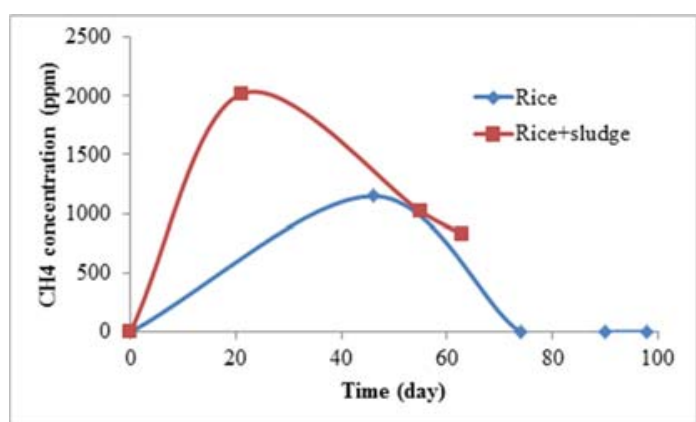

Figure 4d. Methane gas concentration in the biogas produced from rice with and without sludge $\left(\mathrm{T}=35^{\circ} \mathrm{C}\right)$. 


\section{References}

American Public Health Association (1995), Standard methods for the examination of water and waste water. 19th ed. Edited by American Public Health Association, Washington, DC.

Babaee A, Shayegan J (2010), Biogas production: current state and perspectives. Appl. Microbiol Biotechnology 85: 849-860.

Beam R (2011), Enhanced biogas production through optimization of anaerobic digestion of sewage sludge. PhD thesis, The University of Alabama, Department of Chemical and Biological Engineering.

Berlian S, Sukandar A, Seno D (2013), Biogas recovery from anaerobic digestion process of mixed fruit -vegetable wastes. Energy Procedia, 32: 176-182.

Bernd L (2006), Kinetic study of thermophilic anaerobic digestion of solid wastes from potato processing. Biomass and Bioenergy 30: 892-896.

Bouallagui H, Haouari O, Touhami Y, Cheikh R, Marouani L, Hamdi M (2004), Effect of temperature on the performance of an anaerobic tubular reactor treating fruit and vegetable waste. Process Biochemistry 39: 2143-2148.

Bouallagui H, Touhami Y, Cheikh R, Hamdi M (2005), Bioreactor performance in anaerobic digestion of fruit and vegetable wastes. Process Biochemistry 40: 989-995.

Cheng F, Kanokwan B, Irini A (2011), Biogas production from potato-juice, a by-product from potato-starch processing, in up flow anaerobic sludge blanket (UASB) and expanded granular sludge bed (EGSB) reactors. Bioresource Technology 102: 5734-5741.

Chua K, Cheah W, Tan C, Leong Y (2013), Harvesting biogas from wastewater sludge and food waste. $4^{\text {th }}$ International Conference on Energy and Environment, Earth and Environmental Science 16: 012118.

Demirbas A (2006), Biogas production from the organic fraction of municipal solid waste. Energy Sources, Part A, 28: 1127-1134.

Gelegenis J, Georgakakis D, Angelidaki I, Christopoulou N, Goumenaki M (2007), Optimization of biogas production from olive-oil mill wastewater by codigesting with diluted poultry-manure. Applied Energy 84: 646-663.

Kryvoruchko V, Machmuller A, Bodiroza V, Amon B, Amon T (2009), Anaerobic digestion of by-products of sugar beet and starch potato processing. Biomass and Bio Energy 33: 620627.
Liu Y, Miller S, Safferman S (2009), Screening codigestion of food waste water with manure for biogas production. Biofuels, Bioproducts and Biorefining 3: 11-19.

Ma J, Van Wambeke M, Carballa M, Verstraete W (2008), Improvement of the anaerobic treatment of potato processing wastewater in a UASB reactor by co-digestion with glycerol. Biotechnology Letters 30: 861-867.

Machnicka A, Suschka J, Grübel K (2008), The importance of potassium and magnesium ions in biological phosphorus removal from wastewater. Water Environmental Research 80: 617-623.

Martín A, Siles A, El Bari H, Chica F, Martín A (2010), Orange peel: organic waste or energetic resource.ramiran.net/ramiran2010/docs/Ramir an 2010_0083_final.pdf (Accessed 15.02.2015).

Mayer F (1998), Potato pulp: Properties, physical modification and applications. Polymer Degradationa and Stability 59: 231-235.

Nallathambi V (2004), Biochemical methane potential of fruits and vegetable solid waste feedstocks. Biomass and Bioenergy 26: 389-399.

Nasir IM, Ghazi T, Omar R (2012), Production of biogas from solid organic wastes through anaerobic digestion: A review. Applied Microbiology and Biotechnology 95: 321-329.

Nguyen H (2013), Biogas production from solvent pretreated orange peel. M.Sc. Thesis, Department of Chemical and Biological Engineering, Chalmers University of Technology, Goteborg, Sweden.

Nirmala B, Deepak S, Sunil K (1996), Biomethanation of banana peel and pineapple waste. Bioresource Technology 58: 73-76.

Ofoefule A, Onyeoziri M, Uzodinma O (2011), Comparative study of biogas production from chemically-treated powdered and un-powdered rice husks. Journal of Environmental Chemistry and Ecotoxicology 3(4): 75-79.

Okeha O, Onwosib C, Odiboa F (2014), Biogas production from rice husks generated from various rice mills in Ebonyi State. Nigeria Renewable Energy 62: 204-208.

Paramita V, Iida K, Yoshii H, Furuta T (2010), Effect of feed liquid temperature on the structural morphologies of d-limonene microencapsulated powder and its preservation. Journal of Food Science 75(1): 39-45.

Parawira W, Murto M, Read J, Mattiasson B (2005), Profile of hydrolases and biogas production during two-stage mesophilic anaerobic digestion 
of solid potato waste. Process Biochemistry 40: 2945-2952.

Parawira W, Murto M, Zvauya R, Mattiasson B (2004), Anaerobic batch digestion of solid potato waste alone and in combination with sugar beet leaves. Renewable Energy 29: 1811-1823.

Periyasamy E, Nagarajan P (2012), Biogas production from co-digestion of orange peel waste and jatropha de-oiled cake in an anaerobic batch reactor. African Journal of Biotechnology 11(14): 3339-3345.

Saev M, Koumanova B, Simeonov I (2009), Anaerobic co-digestion of wasted tomatoes and cattle dung for biogas production. Journal of the University of Chemical Technology and Metallurgy 44: 55-60.

Salter A (2007), Crops for biogas production; yields, suitability and energy balances IEA Bioenergy, 15 ${ }^{\text {th }}$ European Biomass Conference, Berlin.

Sarada R, Joseph R (1994), Studies on factors influencing methane production from tomatoprocessing waste. Bioresource Technology 47: 55-57.

Satyanarayana S, Murkutea P, Ramakant A (2008), Biogas production enhancement by Brassica compestries amendment in cattle dung digesters. Biomass and Bioenergy 32: 210-215.

Singh A, Kuila A, Sunita A, Moumita B, Rintu B (2012), Utilization of vegetable wastes for bioenergy generation. Agricultural Research 1(3): 213-222.

Song Z, Yang G, Guo Y, Zhang T (2012), Comparison of two chemical pretreatments of rice straw for biogas production by anaerobic digestion Bioresources 7:3223-3236.
Tekin A, Dalgic A (2000), Biogas production from olive pomace, Resources. Conservation and Recycling 30: 301-313.

Velmurugan B, Ramanujam R (2011), Anaerobic digestion of vegetable wastes for biogas production in a fed-batch reactor. International Journal of Emerging Sciences 1(3): 478-486.

Weiland P (2011), Effect of organic loading rates (OLR) on production of methane from anaerobic digestion of vegetables waste. World Renewable Energy Congress, Sweden.

Wikandari R, Nguyen H, Millati R, Niklasson C, Taherzadeh M (2014), Improvement of biogas production from orange peel waste by leaching of limonene. BioMed Research International, Article ID 494182, 1-6.

Ye J, Li D, Sun Y, Wang G, Yuan Z, Zhen F, Wang $Y$ (2013), Improved biogas production from rice straw by co-digestion with kitchen waste and pig manure. Waste Management 33: 2653-2658.

Yogita S, Sumit B, Radhika S (2012), Evaluation of biogas production from solid waste using pretreatment method in anaerobic condition. International Journal of Emerging Sciences 2(3): 405-414.

Zhua B, Gikasb P, Zhang R, Lord J, Jenkins B, Li X (2009), Characteristics and biogas production potential of municipal solid wastes pretreated with a rotary drum reactor. Bioresource Technology 100: 1122-1129. 